\title{
The Roles of Additive Effect between Swine Keeping Systems and Agro-Ecological Zones in Production and Socioeconomic Traits
}

\author{
D. A. Iyai ${ }^{1}$, M. Sagrim ${ }^{2}$, S. Pakage ${ }^{1}$, and A. G. Murwanto ${ }^{1}$ \\ ${ }^{1}$ Department of Animal Husbandry. Faculty of Animal Science. Universitas Papua. Jl. Gunung Salju, \\ Amban. Manokwari-Papua Barat. Postal Code 98314 \\ ${ }^{2}$ Department of Agribusiness. Faculty of Agriculture. Universitas Papua. Manokwari-Papua Barat \\ Postal code 98314 \\ Corresponding email: da.iyai@yahoo.com
}

\begin{abstract}
The aim of this research was to characterize swine farming system performances tethered under different agroecological zones in Papua. The field study was done in Manokwari regency and involved six districts, i.e. Nothern Manokwari district, Eastern Manokari District, Western Manokwari district, Warmare district, Prafi district and Masni district. Respondents chosen were guided by local extensions, originated from 15 villages. Participatory situation analysis (PSA) was employed to approach swine farmers by using questionnaire. Swine body weights of swinelets and growers were weighed except for mature swine, body lengths and hearth girths were measured using tape. Herd number, number of swinelets, adult swine were recorded. A one-way analysis of variances was used. All data were entered in Excel and analyzed using SPPS version 10.0.. The findings shown that interaction between education and keeping systems occur on work hours and ages. Effect of education is significant on experience, location, and ethnic. In keeping systems, effect is real on experience, work hours, location, and ethnic. Interaction do not significant exist in number of swine including see middle man, visited consumer, litter size, number of farrowing and income sources.
\end{abstract}

Key words: swine keeping systems, education, ethnic, litter size, farrowing rate

\section{INTRODUCTION}

Swine keeping systems on tropical and sub-tropical agro-ecosystems on each country tethered in the world are vary. These swine keeping systems depend on resources, in particular feeds such as crops (Iyai, 2015a), residues and other potential edible plants and climate elements (Kruska et al., 2003). Areas where available with crops can have certain animal keeping systems. Shapes and alternation of swine keeping systems tend to be determined by economic effect including income, supply and demand; demographic trend, climates and other important relevant factors. Wet and dry seasons tend to shape livestock keeping systems. Many agro-ecological components have identified contributed in performing livestock keeping systems in Asia (Devendra, 2007). Several classifications of animal agriculture and its definitions can be referred in the articles of Kruska et al. (2003) and Devendra and Thomas (2002).

Other typical agro-ecological elements can be classified into urban and rural or remote areas. Regions such Indonesia has many agroecological areas and/or zones. Farmers most live do farm as key livelihood in rural areas. They are recognised as typical agro-ecological components as growing crops, fertilizer and animal power. Many livestock and crops keeping systems are severely and evidently depended on these components. However, many keeping systems shaped are rarely studied and lagged behind the facts as it should be. Its effects on livestock keeping systems were studied quite often on ruminants, such as cattle, dairy cattle, goat and sheep compared to swine one. In one hand, another livestock commodity which has prospect is the swine. Regions where swine are farmed in Indonesia are scare and limited. North Sumatera, Borneo, Bali, North Sulawesi, Molucca, Flores (including Flobamora) and Papua land are dependent on this animal agriculture (Liano and Siagian, 2002).

Papua has several recognized agroecological zones which the swine are tethered. Similar to other Indonesian regions, islands and mainland are clearly separated including urban and rural areas. Using different agro-ecological zones, it effects have been attached by the knowledge and experience of Papuan farmers. One of their main livelihoods is raising swine (Peters, 2001). Iyai (2008b) and Iyai and Yaku (2015) has classified swine keeping systems into four systems. Other important Papuan 
livelihoods are farming, fishing, hunting and gathering and in few numbers are working as public state officers. Ethnics of Papuan live at urban and mostly on rural areas. Their swine farms tethered and benefit the various agroecological zones have shaped the production of swine. However, its typical and features of these zones are lagging behind. Therefore, the aim of this research was to getting deep quantifying interaction effects on swine farming systems tethered under urban and rural areas in Papua under special cases of Manokwari.

\section{MATERIALS AND METHODS}

\section{Study Sites}

The field study was done in Manokwari regency by surveying six districts, i.e. Nothern Manokwari district, Eastern Manokari District, Western Manokwari district, Warmare district, Prafi district and Masni district (Fig. 1). Manokwari regency, which has a total area of $14,445 \mathrm{~km}^{2}$ and possesses a population of around 161,000 inhabitants with a density of 11,51 head $\mathrm{km}^{-2}$, is located at $132^{\circ} 30^{\prime}-134^{\circ} 45^{\prime}$ East
Meridian and $0^{\circ} 20^{\prime}-2^{\circ} 25^{\prime}$ South latitude. The population in Manokwari is growing in both urban and rural areas, especially in resettlement areas, such as Warmare, Prafi and Masni districts. Respondents chosen were guided by local extension officers and selected purposively from 15 villages. In urban areas selected farmers originated from Anggrem, Borobudur, Fanindi, Wosi, Amban and Susweni villages, while in rural areas selected farmers originated from Tanah Merah, Nimbai, Waseki, Aimasi, Mokwan, Mimbowi, SP-8 Masni, Bremi and Warbefor villages. Three urban villages, Anggrem, Fanindi and Wosi, are situated on coastal areas of Manokwari as well as the two rural villages, i.e. Bremi and Warbefor, which are located in the Northern coastal line of Manokwari. Anggrem, Fanindi and Wosi are located at less than $5 \mathrm{~m}$ ASL. Amban and Susweni are located at $110 \mathrm{~m}$ ASL. The rural villages Bremi and Warbefor, are located less than 5 meter ASL. While most villages in Prafi valley, such as Tanah Merah, Waseki, Nimbai, Aimasi, Mokwan, Mimbowi and SP-8 are located at about 20 to 25 meter ASL.

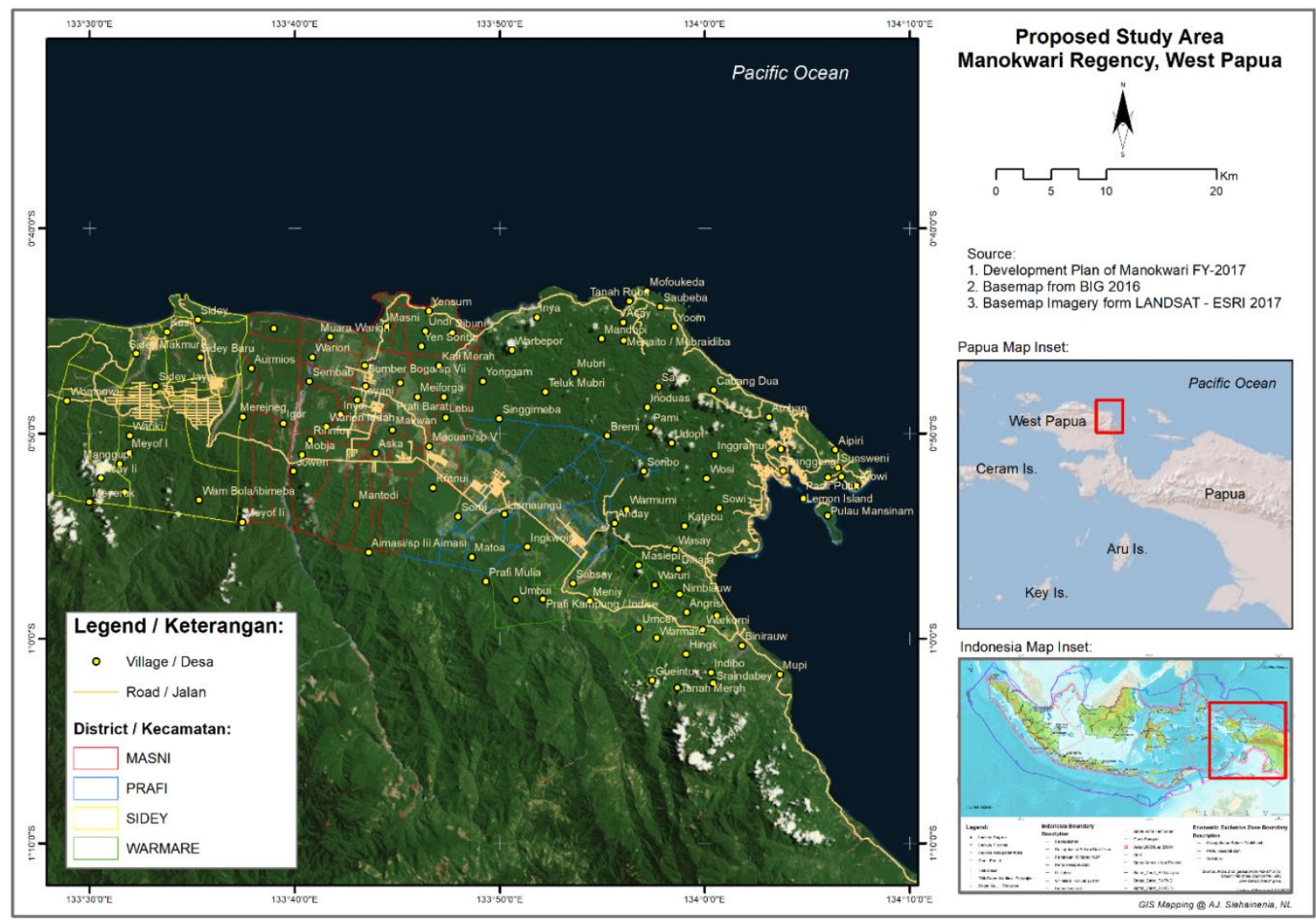

Figure 1. Study site location done in several urban and rural areas of Manokwari. 


\section{Research Approach and Parameters.}

Participatory situation analysis (Conroy, 2005) was employed to approach selected and participated 49 swine farmers. From those farmers, 21 households had free-ranges, 13 semipen (semi intensive) and 15 using pen farms (intensive keeping systems). Urban pig farmers involved 20 households and rural farmers were 29 households. Interviews using questionnaire was done to gather information from all swine farmers. Tropical livestock unit (TLU) of the swine is 0.25 from body weight.

\section{Statistical Analysis.}

General model of interaction is proposed as followed Yijk $=u+\alpha i+\beta j+(\alpha * \beta) i j+$ $\varepsilon i j k$, where $\mathrm{i}=1,2,3 ; \mathrm{j}=1,2 ; \mathrm{k}=1, \ldots, 5$. Where Yijk is swine farming production parameters, $\mathrm{u}$ is intercept, $\alpha \mathrm{i}=$ additive effect of swine keeping systems ( $1=$ free range, $2=$ semi-pen, $3=$ pen), $\beta \mathrm{j}$ is agro-ecological zones (1=urban effect and $2=$ rural effect), and $\Upsilon=$ Interaction between swine keeping systems and agro-ecological zones.cijk=effect of errors with normal distribution, N (0, I) (Gaspersz, 1991; Ott and Longnecker, 2001). A one-way analysis of variances was used. Qualitative and quantitative data were entered in Excel database (2003).
Analysis of data using SPPS version 10.0., was used.

\section{RESULTS AND DISCUSSION}

\section{On-farm Social Assets Overview}

The Levene's test of equality of error variances shown that variables such as household member, ages, experience, work hours, visited consumer, litter size, household size had equal variances $(\mathrm{P}<0.05)$. However, variables such number of swine, number of Tropical Livestock Unit (TLU) of swine, see middlemen, number of farrowing, ethnic, education level and income source were varying $(\mathrm{P}>0.05)$.

Farmers background of the current study (Table 1.) presented household members (Fig.2.), experience (Fig.3.), work hours (Fig.4.), ethnic (Fig.5.), ages (Fig.6.) and education level (Fig.7.) of farmers. The number of household member shown small to middle number of household members. Smaller number in semi intensive

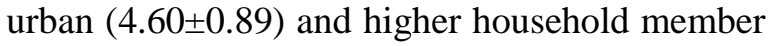
found in intensive keeping systems and was in urban agro-ecological areas $(7.91 \pm 4.06)$. No significant difference $(\mathrm{P}>0.05)$ found on household member and education level (Dione $e t$ al., 2014; Iyai et al., 2018; Iyai, 2015).

Table 1. Description of swine farmers background

\begin{tabular}{|c|c|c|c|c|c|c|c|c|}
\hline \multirow{3}{*}{ Variables } & \multirow{3}{*}{ Unit } & \multicolumn{2}{|c|}{ Free-range } & \multicolumn{2}{|c|}{ Semi-Intensive } & \multicolumn{2}{|c|}{ Intensive } & \multirow[t]{3}{*}{ Sig. } \\
\hline & & Urban & Rural & Urban & Rural & Urban & Rural & \\
\hline & & $\dot{\mathrm{x}} \pm$ SEM & $\dot{\mathrm{x}} \pm \mathrm{SEM}$ & $\dot{\mathrm{x}} \pm \mathrm{SEM}$ & $\dot{\mathrm{x}} \pm$ SEM & $\dot{\mathrm{X}} \pm \mathrm{SEM}$ & $\dot{\mathrm{x}} \pm$ SEM & \\
\hline Hh_mbr & Head & $5.25 \pm 2.06$ & $6.41 \pm 3.08$ & $4.60 \pm 0.89$ & $5.12 \pm 2.03$ & $7.91 \pm 4.06$ & $4.50 \pm 1.29$ & ns \\
\hline Experience & Year & $30.50 \pm 12.76$ & $26.97 \pm 15.66$ & $28.20 \pm 9.31$ & $23.12 \pm 15.24$ & $20.00 \pm 16.22$ & $1.97 \pm 2.69$ & $*$ \\
\hline Work_Hrs & Hour & $1.37 \pm 0.75$ & $1.32 \pm 0.43$ & $1.60 \pm 0.54$ & $2.25 \pm 0.89$ & $1.95 \pm 0.91$ & $3.25 \pm 1.26$ & $*$ \\
\hline Ethnic & & $1.00 \pm 0.00$ & $1.23 \pm 0.43$ & $2.00 \pm 0.00$ & $1.25 \pm 0.46$ & $1.27 \pm 0.46$ & $1.00 \pm 0.00$ & $*$ \\
\hline Age & Year & $53.25 \pm 8.02$ & $47.94 \pm 9.18$ & $44.40 \pm 11.67$ & $46.00 \pm 14.86$ & $37.00 \pm 13.69$ & $46.75 \pm 2.75$ & $*$ \\
\hline Edu level & & $1.50 \pm 0.58$ & $1.94 \pm 0.66$ & $1.60 \pm 0.54$ & $1.62 \pm 0.92$ & $1.72 \pm 0.01$ & $1.25 \pm 0.50$ & ns \\
\hline
\end{tabular}

*Significant at $\mathrm{P}<0.05$, ns: not significant.

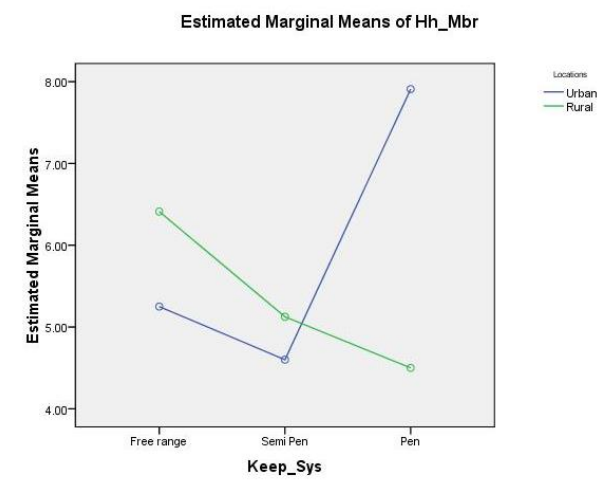

Fig. 2. Interaction effect of keeping systems and agroecological areas on household member.

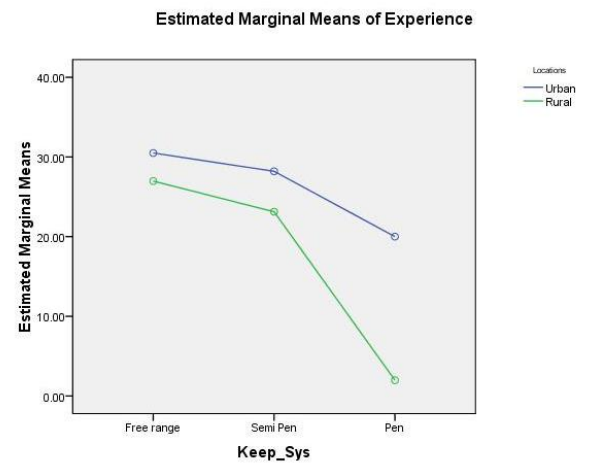

Fig. 3. Interaction effect of keeping systems and agroecological areas on farmers' experience. 


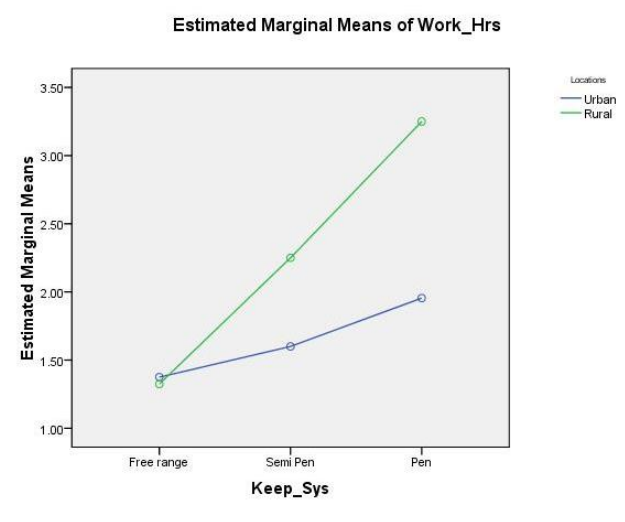

Fig. 4. . Interaction effect of keeping systems and agroecological areas on work hours

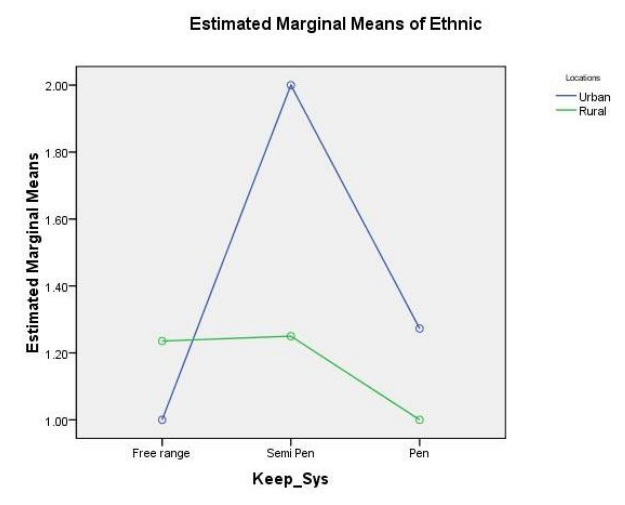

Fig. 5. . Interaction effect of keeping systems and agroecological areas on ethnics.

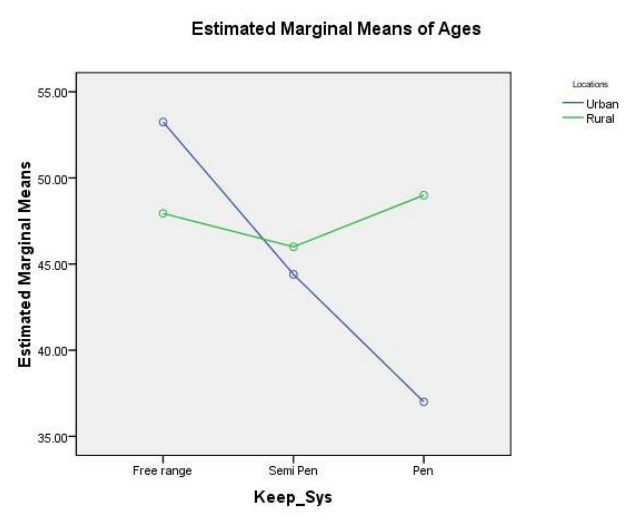

Fig. 6. Interaction effect of keeping systems and agroecological areas on farmers' ages.

From work hours, higher work hours spent by farmers was found on interaction of intensive* rural (3.25 \pm 1.26$)$, followed by intensive*urban. Lower work hours found in interaction between free range*rural. Ethnic who are doing keeping swine found higher on semiintensive* urban. Ethnic raising swine consisted of Papuan native and non-Papuan tribes. We also interested in observing the ages of farmers. It seems that farmers had higher ages found in freerange*urban (53.25 \pm 8.02$)$, followed by semiintensive* rural farmers $(46.00 \pm 14.86)$ and freerange*rural farmers $(47.94 \pm 9.18)$. No significant different based on education level found.

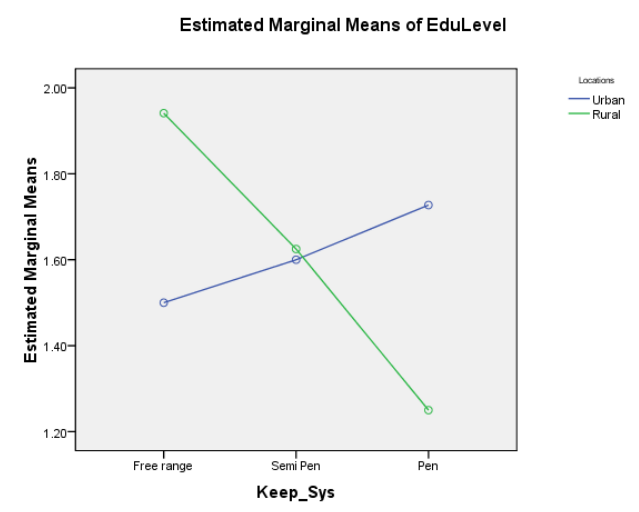

Fig. 7. Interaction effect of keeping systems and agroecological areas on education level.

Ages of swine farmers had interaction effect on swine keeping systems and agroecological areas. This occurs by means that farmers have choices in developing their typical keeping systems wherever they can and whatever they have capable of. Factors in determining how extend keeping systems developed depend on resources available such as cash, materials and areas. Besides, knowledge and policy provided for are important urgently needed by the farmers.

Household members living in farmer house as family and close relatives are common for Papua farmers. They are living ranged from small to big group. One house can accommodate one to three households. It meant that the more education level obtained by farmers and escalation of keeping system from extensive till intensive farming systems had no effect on the dynamic number of household member living inside family of swine farmers. We found also an interesting trend on experience. Education levels and keeping systems of the swine had not determined experience. It means that, changes in educations and keeping systems had no contribution on experiences. Experiences of a farmers will then be resulted from informal education and how farmers tethered their farming business (Fynbo and Jensen, 2018; Boogaard et al., 2011; Lassen et al., 2006; Correia-Gomes et al., 2017).

Another case found on work hours. The interaction effect between keeping systems and 
agro-ecological areas had significant point $(\mathrm{P}<0.05)$. Location where farming business are established had indeed determine work hours by reason that farmers had time in managing its business at that time. Farmers who are living and making their business at quality chances can have optimal production compared to farmers with limited quality changes. Many factors determine the optimal production such as busyness, resources allocation, aids given by government and so forth. Quality chances can stimulate optimal production and finally will bring farmers in higher revenues and incomes.

\section{Swine Production and Economic Indicators}

It seems that number of swine (herd size)

kept by farmers was higher on interaction of semi-intensive*urban $\quad(18.60 \pm 16.22)$. It was higher than that reported by Iyai (2009) in Manokwari, i.e. only 5 head/household. It seems that there is an effect and/or interaction of agro- ecological areas with keeping systems on herd size (Fig. 8). Urban farmers tend to more focus and being intensive in raising swine compared to rural intensive. Number of swine (herding size) is an indicator explaining living asset that belongs and keeps a live by a farmer (Holt et al., 2019; Wabacha et al., 2004).

Number of swine raised based on tropical livestock unit was then higher ( $>1$ TLU) as well in urban*intensive interaction rather than those two other interaction (Fig. 9.). See middle men (retailers) experienced by small-scale swine farmers in Manokwari (Fig. 10.). The figure shown no different of interaction between keeping systems with agro-ecological areas (p>0.05). It meant that middle men (Fig. 10.) could have similar changes to approach farmers for transaction of selling-buying process. The finding of visiting consumers was similar no significant different (Fig. 11).

Table 2. Production and income traits of swine keeping systems

\begin{tabular}{|c|c|c|c|c|c|c|c|c|}
\hline \multirow{3}{*}{ Variables } & \multirow{3}{*}{ Unit } & \multicolumn{2}{|c|}{ Free-range } & \multicolumn{2}{|c|}{ Semi-Intensive } & \multicolumn{2}{|c|}{ Intensive } & \multirow{3}{*}{ Sig } \\
\hline & & Urban & Rural & Urban & Rural & Urban & Rural & \\
\hline & & $\dot{\mathrm{x}} \pm$ SEM & $\dot{\mathrm{x}} \pm$ SEM & $\dot{\mathrm{x}} \pm$ SEM & $\dot{\mathrm{x}} \pm$ SEM & $\dot{\mathrm{x}} \pm$ SEM & $\dot{\mathrm{x}} \pm$ SEM & \\
\hline No. swine & $\mathrm{Head} / \mathrm{hh}$ & $5.5 \pm 2.51$ & $5.12 \pm 2.95$ & $18.60 \pm 16.22$ & $8.25 \pm 3.84$ & $8.75 \pm 10.35$ & $7.48 \pm 4.81$ & $*$ \\
\hline No. TLU & $A U / h h$ & $1.37 \pm 0.63$ & $1.28 \pm 0.74$ & $4.65 \pm 4.16$ & $2.06 \pm 0.96$ & $1.36 \pm 1.29$ & $4.00 \pm 0.58$ & $*$ \\
\hline See mid.men & $\mathrm{Fr} / \mathrm{hh}$ & $2.00 \pm 0.82$ & $1.41 \pm 0.62$ & $1.80 \pm 0.84$ & $1.25 \pm 0.71$ & $1.27 \pm 0.79$ & $1.00 \pm 0.82$ & ns \\
\hline Visit consumers & $F r / h h$ & $0.75 \pm 0.96$ & $0.82 \pm 0.73$ & $1.40 \pm 0.55$ & $0.63 \pm 0.74$ & $1.54 \pm 1.36$ & $0.25 \pm 0.50$ & ns \\
\hline Litter size & Tail/sow & $6.00 \pm 1.15$ & $5.35 \pm 1.83$ & $6.40 \pm 3.13$ & $6.88 \pm 1.64$ & $4.91 \pm 2.55$ & $6.75 \pm 1.26$ & ns \\
\hline No. Farrowing & $F r / y r$ & $1.75 \pm 0.50$ & $1.00 \pm 0.71$ & $1.86 \pm 0.35$ & $1.87 \pm 0.35$ & $1.54 \pm 0.52$ & $1.50 \pm 1.00$ & ns \\
\hline Income & Fr/yr & $1.00 \pm 0.00$ & $2.00 \pm 0.61$ & $1.00 \pm 0.00$ & $1.75 \pm 0.46$ & $2.00 \pm 0.00$ & $3.00 \pm 0.00$ & $*$ \\
\hline
\end{tabular}

*Significant at $\mathrm{p}<0.05$, ns: not significant. TLU: tropical livestock unit.

Litter size of the swine kept by farmers was expected different due to interaction. However, the fact was different. The finding shown us that no interaction $(p>0.05)$ was found in litter size number. The higher number of litter size found in interaction of semi-intensive*urban farmers, followed by interaction effect of intensive* rural, free-range*urban, semiintensive rural.

This figure has an effect as well on farrowing number per sow/household. Farrowing rate which could be achieved by local swine farmers did not differ amongst swine farmers. It meant that farrowing rate of each gilt and/or sow was lower than that expected by the farmers which could get 3 times $y^{-1}$. Income source found significant difference in interaction between keeping systems and agro-ecological areas $(\mathrm{P}<0.05)$. It is apparently seen that development of swine keeping systems in West
Papua established without linearity with level of education. The effect is too small and depended on other factors.

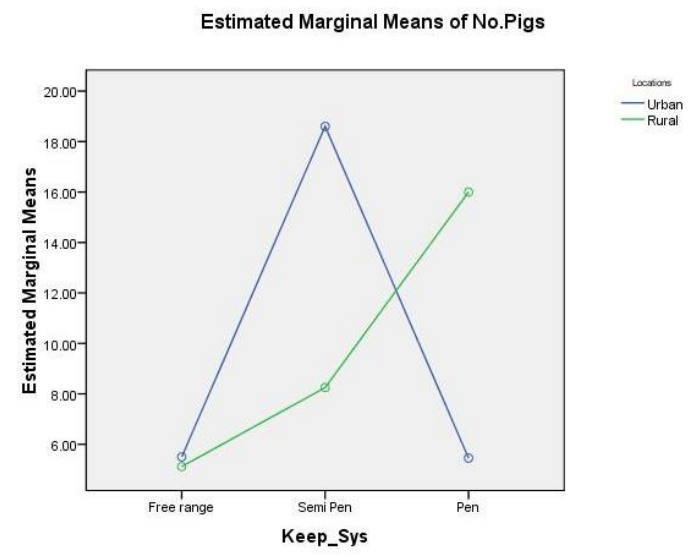

Fig. 8. . Interaction effect of keeping systems and agroecological areas on number of swine. 


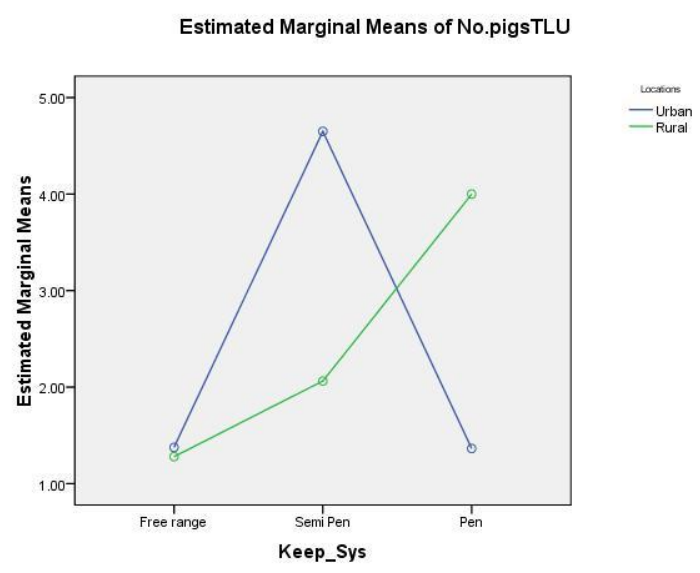

Fig.9. Interaction effect of keeping systems and agroecological areas on tropical livestock unit.

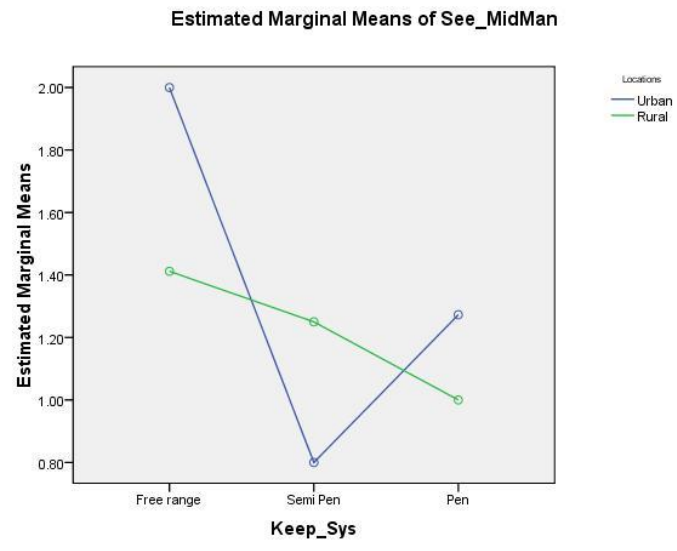

Fig. 10. Interaction effect of keeping systems and agroecological areas on seeing middle men.

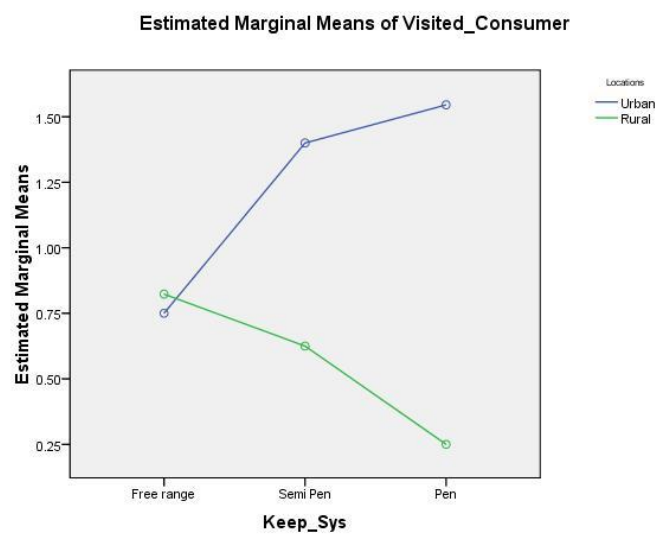

Fig. 11. Interaction effect of keeping systems and agroecological areas on visited consumers.

Seeing interaction effect of keeping systems and agro-ecological areas will enable farmers to improve their swine productivities on scales and time. It seems that there are four indicators that have significant effect on interaction, i.e. experience, work hours, ethnic and ages subsequently (Iyai, 2010; Muhanguzi et al., 2012; Baxter and Edwards, 2017; Olson et $a l ., 2003)$. The rest were not significant proven.

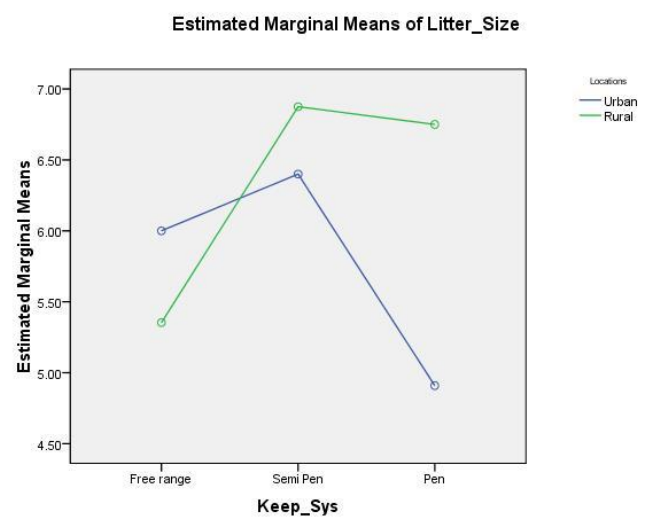

Fig. 12. Interaction effect of keeping systems and agroecological areas on litter size

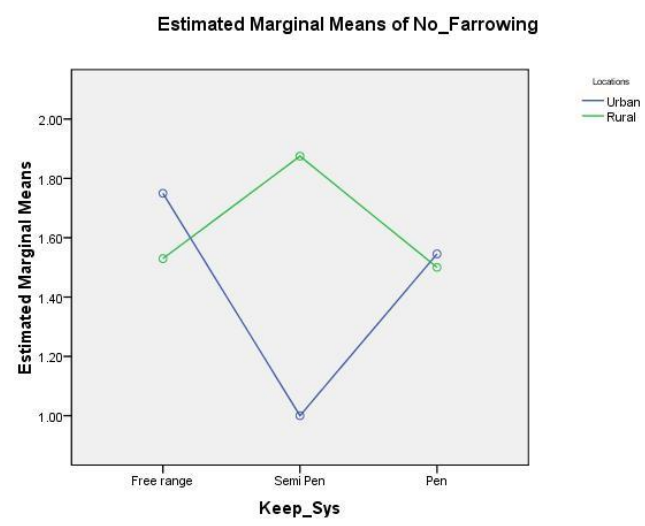

Fig. 13. Interaction effect of keeping systems and agroecological areas on farrowing frequency.

Understanding swine production performances will enable decision making getting more easy and precise on selecting swine production traits and broad design on economic efficiency (Govoeyi et al., 2019; Muhanguzi et al., 2012; Ouma et al., 2013; Zebua and Siagian, 2017; Mayer et al., 2002; Iyai, 2010; de Barcellos et al., 2013; Wabacha et al., 2004). The more educated a person will be, the more keeping systems will be shifted from extensive to intensive systems.

General discussion on this interaction study shown and shall highlights several facts that household size is independent and not determined by interaction of keeping systems and agro-ecological areas and added to this 
education level. In production and income traits, seeing middle men and visited consumers are independent. Consumers and buyers have free choices in determining producers. The markets of swine occur in free choices. However, number of swine (herd size), animal unit (TLU), and income have interaction effects (Iyai, 2020; Iyai et al., 2011; Widayati et al., 2018). The more herd swine is kept, the more consumers can have possibilities in selling a number of pigs and in turn delivering cash for the farmers. Therefore, farmers need to provide good livestock farm management in good manner to enhancing big market. Good livestock farming practices (Muhanguzi et al., 2012; Lassen et al., 2006; Holt et al., 2019; Sysak et al. 2012; Rivai, 2011; Kijlstra and Eijck 2006) will bring future prospect for the good business of swine production systems.

\section{CONCLUSIONS}

We conclude that interaction between keeping systems and agro-ecological areas occur on experiences, work hours, ethnic and ages. In one hand, production and income can be derived from herd sizes, and in turn increasing income of the swine business.

\section{ACKNOWLEDGMENT}

We thanked staffs of Extension office, Livestock and Veterinary Provincial Office, all households and private enterprises for sharing data and information.

\section{REFERENCES}

Barcellos, M. D., K. G. Grunert, Y. Zhou, W. Verbeke, F. J.A. Perez-Cueto, and A. Krystallis. 2013. Consumer Attitudes to Different Pig Production Systems: A Study from Mainland China. Agriculture and Human Values. 30 (3): 443-55. https://doi.org/10.1007/s10460-0129416-4.

Baxter, E. M., and S. A. Edwards. 2017. Piglet Mortality and Morbidity. Advances in Pig Welfare, 73-100. https://doi.org/10.1016/b978-0-08101012-9.00003-4.
Boogaard, B. K., L. J.S. Boekhorst, S. J. Oosting, and J. T. Sørensen. 2011. Socio-Cultural Sustainability of Pig Production: Citizen Perceptions in the Netherlands and Denmark. Livestock Science 140 (1-3): 189-200. doi.org/10.1016/j.livsci.2011.03.028

Correia-Gomes, C., M. K. Henry, H. K. Auty, and G. J. Gunn. 2017. Exploring the Role of Small-Scale Livestock Keepers for National Biosecurity-The Pig Case. Preventive Veterinary Medicine 145: $7-$ 15.doi.org/10.1016/j.prevetmed.2017.06.005.

Devendra, C. 2007. Perspectives on Animal Production Systems in Asia. 106: 1-18. https://doi.org/10.1016/j.livsci.2006.05.0 05 .

Devendra, C. and D. Thomas. 2002. Crop Animal Systems in Asia: Importance of Livestock and Characterisation of AgroEcological Zones 71: 5-15.

Dione, M. M., E. A. Ouma, K. Roesel, J. Kungu, P. Lule, and D. Pezo. 2014. Participatory Assessment of Animal Health and Husbandry Practices in Smallholder Pig Production Systems in Three High Poverty Districts in Uganda. Preventive Veterinary Medicine 117 (3-4): 565-76. https://doi.org/10.1016/j.prevetmed.2014 .10 .012 .

Fynbo, L., and C. S. Jensen. 2018. Antimicrobial Stigmatization: Public Health Concerns about Conventional Pig Farming and Pig Farmers' Experiences with Stigmatization. Social Science and Medicine 201 (September 2017): 1-8. https://doi.org/10.1016/j.socscimed.2018. 01.036 .

Gaspersz, V. 1991. Metode Perancangan Percobaan untuk Ilmu-Ilmu Pertanian, Ilmu-Ilmu Teknik, dan Biologi. 2nd ed. Bandung: Armico.

Govoeyi, B., S. G. Ahounou, A. M. Agbokounou, C. F.A. Salifou, I. O. Dotche, P. S. Kiki, I. Y. A. Karim, and 
N. Antoine-Moussiaux. 2019. Participatory Innovation Analysis along Livestock Value Chains: Case of Swine Value Chain in Benin. Agricultural Systems 174 (April): 11-22. https://doi.org/10.1016/j.agsy.2019.04.00 7.

Greef, K. H. de, H. M. Vermeer, H. W.J. Houwers, and A. P. Bos. 2011. Proof of Principle of the Comfort Class Concept in Pigs. Experimenting in the Midst of a Stakeholder Process on Pig Welfare. Livestock Science 139 (1-2): 172-85. https://doi.org/10.1016/j.livsci.2011.03.0 05.

Holt, H. R., P. Inthavong, K. Blaszak, C. Keokamphe, A. Phongmany, S. D. Blacksell, P. A. Durr, et al. 2019. Production Diseases in Smallholder Pig Systems in Rural Lao PDR. 162 (August 2018):

$110-16$. https://doi.org/10.1016/j.prevetmed.2018 .11.012.

Iyai, D. A., B. W. I. Rahayu, I. Sumpe, and D. Saragih. 2011. Analysis of Pig Profiles on Small-Scale Pig Farmers in Manokwari-West Papua. Journal of the Indonesian Tropical Animal Agriculture 36 (3): 190-97.

Iyai, D., Rahayu, B., Sumpe, I., \& Saragih, D. (2011). Analysis of Pig Profiles on Small-Scale Pig Farmers In ManokwariWest Papua. Journal of the Indonesian Tropical Animal Agriculture, 36(3), 190197. https://doi.org/10.14710/jitaa.36.3.1 90-197

Iyai, D. A., and A. Yaku. 2015. Identifikasi Sistim Peternakan di Manokwari, Papua Barat-Indonesia. The Identification of Livestock Farming Systems in Manokwari, West Papua-Indonesia. Jurnal Peternakan Indonesia 17 (2): 94 104.

Iyai, D. A. 2015. Identifikasi Sistim Peternakan di Manokwari, Papua Barat-Indonesia. Jurnal Peternakan Indonesia (Indonesian Journal of Animal Science). https://doi.org/10.25077/jpi.17.2.94105.2015.
Iyai, D. A. 2015. Pola Gender dalam Peternakan Babi pada Peternak Etnis Arfak, Papua Barat Gender Pattern in Pig Farming Systems of Arfak Ethnic , West Papua 13 (1): 22-35.

Iyai, D. A. 2010. Sosial-Ekonomi, Penilaian Pendefinisian Faktor-Faktor Peternakan, Sistem Barat, Papua. Jurnal Ilmu Peternakan 5 (1): 35-45.

Kanis, E., A. B. F. Groen, and K. H. De Greef. 2003. Societal Concerns about Pork and Pork Production and Their Relationships to the Production System. Journal of Agricultural and Environmental Ethics 16 (2): 137-62. https://doi.org/10.1023/A:1022985913847.

Kijlstra, A, and I. A. J. M. Eijck. 2006. Animal Health in Organic Livestock Production Systems: A Review. NJAS Wageningen Journal of Life Sciences 54 (1): 77-94. https://doi.org/10.1016/S15735214(06)80005-9.

Kruska, R L, R S Reid, P K Thornton, and N Henninger. 2003. Mapping LivestockOriented Agricultural Production Systems for the Developing World. 77: 39-63. https://doi.org/10.1016/S0308521X(02)00085-9.

Lassen, J., P. Sandøe, and B. Forkman. 2006. Happy Pigs Are Dirty! - Conflicting Perspectives on Animal Welfare. Livestock Science 103 (3): 221-30. https://doi.org/10.1016/j.livsci.2006.05.0 08 .

Mayer, J. J., F. D. Martin, and I. L. Brisbin. 2002. Characteristics of Wild Pig Farrowing Nests and Beds in the Upper Coastal Plain of South Carolina. Applied Animal Behaviour Science 78 (1): 1-17. https://doi.org/10.1016/S01681591(02)00114-4.

Muhanguzi, D., V. Lutwama, and F. N. Mwiine. 2012. Factors that Influence Pig Production in Central Uganda - Case Study of Nangabo Sub-County, Wakiso District. Veterinary World 5 (6): 346-51. 
https://doi.org/10.5455/vetworld.2012.34 6-351.

Olson, P. D., V. S Zuiker, S. M. Danes, K. Stafford, R. K. Z. Heck, and K. A. Duncan. 2003. The Impact of the Family and the Business on Family Business Sustainability. Journal of Business Venturing 18: 639-66. https://doi.org/10.1016/S08839026(03)00014-4.

Ott, R. L. and M. Longnecker. 2001. An Introduction to Statistical Methods and Data Analisys. 5th ed. USA: Duxbury.

Ouma, E. A., M. M. Dione, P. Lule, K. Roesel, L. Mayega, D. Kiryabwire, G. Nadiope, and D. Pezo. 2013. Characterization of Smallholder Pig Production Systems in Uganda. Livestock Research for Rural Development $26 \quad$ (3): 2014. http://hdl.handle.net/10568/29094.

Rivai, R. S. 2011. Berkelanjutan di Indonesia. Concept and Implementation of Sustainable Agricultural Development in Indonesia, 13-25.

Staaveren, N. Van, B. Doyle, and A. Hanlon. Multi-Stakeholder Focus Groups on Potential for Meat Inspection Data to Inform Management of Pig Health and Welfare on Farm. https://doi.org/10.3390/agriculture90200 40.
Sysak, T., P. K. Holyoake, R. Beilin, J. Gilmour, M. Hernández-Jover, J.-A.L.M.L. Toribio, and N. Schembri. 2012. Use of Stakeholder Analysis to Inform Risk Communication and Extension Strategies for Improved Biosecurity amongst Small-Scale Pig Producers. Preventive Veterinary Medicine 104 (3-4): 258-70. https://doi.org/10.1016/j.prevetmed.2011 .12 .006 .

Wabacha, J. K., J. M. Maribei, C. M. Mulei, M. N. Kyule, K. H. Zessin, and W. OluochKosura. 2004. Health and Production Measures for Smallholder Pig Production in Kikuyu Division, Central Kenya. Preventive Veterinary Medicine 63 (34): 197-210. https://doi.org/10.1016/j.prevetmed.2004 .02 .006 .

Widayati, T.W, I Sumpe, B.W. Irianti, D.A. Iyai, and S.Y. Randa. 2018. Faktor- Faktor yang Mempengaruhi Produksi Usaha Ternak Babi di Teluk Doreri Kabupaten Manokwari. Agrika 12.

Zebua, C. K. N., and P. H. Siagian. 2017. Comparative Performances of Landrace, Yorkshire and Duroc Breeds of Swine. Journal of the Indonesian Tropical Animal Agriculture 42 (3): 147-52. https://doi.org/10.14710/jitaa.42.3.147152. 